\title{
“IMIGRANTES”, “IMIGRADOS”, “ESTRANGEIROS”... E A FABRICAÇÃO DO “OUTRO” IMAGINÁRIO. A PRESENÇA BRASILEIRA NO CONTEXTO DA IMIGRAÇÃO NA ESPANHA
}

\author{
Leonardo Cavalcanti ${ }^{1}$
}

\section{Resumo}

No âmbito do atual debate sobre o fenômeno das migrações internacionais contemporâneas, o presente texto procura analisar a construção sócio-cultural da figura do "imigrante", no contexto urbano. A partir do trabalho de campo antropológico realizado pelo autor sobre o coletivo brasileiro radicado na cidade de Barcelona, o presente artigo trata de analisar as linhas gerais da imigração brasileira no cotidiano espanhol, através de diferentes interfaces. Com base na análise de alguns aspectos do coletivo brasileiro, é possível visualizar com mais profundidade diversos elementos que caracterizam a construção do imigrante como um "outro" imaginado.

Palavras-chave: Migração; Espanha; Imigrantes Brasileiros;

\footnotetext{
“Todas las cosas derechas mienten, murmuró con desprecio el enano.

Toda verdad es curva, el tiempo mismo es un círculo." (Y así habló Zaratustra -

Nietzsche )
}

Uma das questões atuais que vem ocupando continuamente as principais pautas nas agendas de governos e organismos internacionais é sem dúvida a temática das migrações. Se as mobilidades humanas, como já se sabe, foi uma constante através das páginas da história, nas últimas décadas, o fenômeno migratório ganhou um protagonismo singular no cenário internacional. Para Massey (1998), a influência da chamada economia pósindustrial, a partir dos anos 70, e as importantes transformações geopolíticas do ocidente no século XX, que foram de diversas ordens e em esferas distintas da sociedade, também

\footnotetext{
${ }^{1}$ Pesquisador Pós-doutoral, programa Juan de la Cierva, CEDIME - Universidad Autonoma de Barcelona Espanha.
} 
alteraram de modo radical as imagens e as idéias sobre as migrações. O número de pessoas que se deslocam atualmente ganhou uma proporção tão elevada que alguns autores, como Castles e Miller (1993), chegam a sugerir que vivemos na era das migrações. Os movimentos migratórios se inseriram como um processo inerente as grandes mudanças mundiais, fazendo com que países caracterizados pela imigração se converteram em pouco tempo em países exportadores de mão de obra ou vice-versa ${ }^{2}$.

O Brasil, a exemplo de muitos países, se viu fortemente influenciado por essa dinâmica. Se até a segunda metade do século XX, a nação brasileira estava fortemente marcada pelo fenômeno da imigração internacional, a partir da década de oitenta ou da chamada "década perdida" ${ }^{3}$, houve uma inversão nesse processo ${ }^{4}$. Uma considerável parte da população brasileira começou a protagonizar uma nova realidade na história do país, penetrando desse modo, no quadro dos países exportadores de mão de obra ${ }^{5}$. A chamada emigração dos brasileiros começa a ser uma realidade cada vez mais freqüente.

Essa realidade provoca diversamente nossas sensibilidades e, como é lógico, o chamado cientista social ou humano não pode resistir à inquietação de produzir conhecimento sobre um fenômeno cuja presença é cada vez mais intensa nos meios de comunicação, nos discursos políticos, nas conversas informais, nas ruas e nos diversos aspectos da vida cotidiana. Seduzido por essas inquietudes e baseado na experiência urbana dos brasileiros radicados na Espanha ${ }^{6}$, gostaria de pensar e fazer pensar sobre a construção social daquele que é denominado "imigrante" na cidade. Portanto, não se trata, aqui, de descrever ou analisar a existência de certos fluxos migratórios e sim de aprofundar epistemologicamente as diferentes miradas de um fenômeno que é construído coletivamente e que se constitui como um fenômeno social.

\footnotetext{
${ }^{2}$ Como por exemplo, os casos do Brasil e da Espanha, ainda que ambos os países tenham trajetórias distintas.

${ }^{3}$ Expressão utilizada pelos economistas latino-americanos para caracterizar a década de 1980 na América Latina como um período em que houve uma forte caída dos indicadores econômicos.

${ }^{4}$ Para conhecer com detalhes as diferentes etapas e contextos históricos do processo migratório no Brasil, consultar Reis e Sales (1999).

${ }^{5}$ Isto não significa desconhecer que no Brasil continua existindo tanto uma migração interna, assim como a presença de coletivos estrangeiros específicos, como é o caso dos bolivianos em São Paulo, aprofundado nos trabalhos de Silva (1997).

${ }^{6} \mathrm{O}$ conhecimento sobre essa realidade resulta do trabalho de campo realizado pelo autor com o objetivo construir sua tese doutoral, que teve como temática o estudo dos imigrantes brasileiros na cidade de Barcelona, consultar Cavalcanti (2003).
} 
No mesmo espaço temporal em que o Brasil passou a se caracterizar por ser um país exportador de mão-de-obra, a Espanha inicia um caminho inverso. A imigração extracomunitária vem se constituindo cada vez mais como uma nova categoria social no país. Qualquer cidadão das mais diversas províncias espanholas, pode facilmente perceber por meio do discurso político, da mídia, da academia $^{7}$ e da opinião pública em geral, a idéia de que, nos últimos anos, consolidou-se com caráter aparentemente definitivo a designação da Espanha como um país de imigrantes.

Essa caracterização é muito recente e podemos situá-la historicamente, a fim de estabelecer um marco cronológico, em torno de dois acontecimentos: por um lado, o ingresso da Espanha na Comunidade Européia, em 1986; por outro, sua posterior adesão ao acordo Schegen, em 1991, assinado para regular a livre circulação de pessoas na União Européia. Esses fatos impulsionaram a economia espanhola, promovendo um fluxo cada vez maior de imigrantes procedentes de diversas regiões do mundo. Posteriormente, será na década de 1990 quando uma afluência maior e mais crescente de imigrantes originários fundamentalmente da África, da América Latina e da chamada Europa do Leste, consolidam a imagem desse país como receptor de estrangeiros extra-comunitários, conforme nos dizem Colectivo Ioé (1999) e Cachón (2002).

O fenômeno da imigração na Espanha se converteu em um tema comum, compartilhado tanto pelos formadores de opinião pública, pelas universidades, pelos meios de comunicação de massa, pelas instâncias políticas, etc., como pela conversa informal no meio popular. Da mesma forma, também aumentou a representação predominantemente "miseralista" e "culturalista" daqueles que são rotulados como "imigrantes". Dessa forma, as pessoas originárias do chamado "terceiro mundo" que vivem no território espanhol são acusadas constantemente de todas as mazelas e desgraças possíveis. A sua presença, identificada, com frequiência, como procedente de uma região atrasada e pouco civilizada, em geral, é percebida como demograficamente excessiva. A existência de distintos

\footnotetext{
${ }^{7}$ Segundo os dados da base TESEO (http://www.mcu.es/TESEO, último acesso: 07 de outubro de 2002), registram-se 155 teses doutorais realizadas em universidades espanholas sobre temáticas relacionadas à dinâmica migratória. Nesse novo interesse da academia na Espanha, encontram-se implicadas disciplinas como a antropologia, a sociologia, a geografia, a psicologia, a pedagogia, a lingüística, a história, a demografia, etc.
} 
mecanismos sociais que colocam os imigrantes em situação de desproteção permite levar a cabo praticas de marginação e exploração, em que muitos pensadores não duvidam em advertir que se trata de novas formas de racismo e discriminação.

\section{A "fabricação" da categoria "imigrante"}

A conversão do "fenômeno" da migração em um "problema" social é um fato que ocorre de modo acentuado tanto na Espanha, como em outros países da Europa. A associação do "imigrante" como um tema público, antes mesmo que ele seja configurado como ator político, representa uma dinâmica que ocorre continuamente em distintos países. Tanto os discursos dominantes, enunciados pelos agentes sociais que exercem influencia na opinião pública, como os diálogos cotidianos no meio popular, insistem continuamente em categorizar o imigrante como um outro.

No entanto, seria oportuno questionar as chamadas ciências sociais ou humanas, a fim de entender o que define o imigrante como uma categoria social. A propósito, caberia o questionamento sobre quem na cidade merece ser definido e taxado como imigrante. Sabese que o termo imigrante procede da demografia e faz referencia a uma pessoa que saiu de seu lugar de origem para viver em outro. Seguindo essa lógica, Delgado (1996) indaga sobre a validez desse argumento, no âmbito da produção acadêmica, dado que a expressão imigrante constitui um particípio do presente, que indica um estado ainda em trânsito. Sendo assim, somente poderia ser denominado imigrante uma pessoa que acaba de chegar, uma figura efêmera que logo será absorvido pela dinâmica da urbe. Para quem já está estabelecido no seu lugar de destino, haveria, então, que se empregar o termo "imigrado". Seguindo esse raciocínio, seria mais paradoxal ainda falar de imigrantes de "segunda ou terceira geração", dado que se estaria identificando-os pelos deslocamentos de seus ascendentes, marcando-os, assim, com uma espécie de "pecado natural" ou uma marca indelével de "imigridade", quando, de fato, já estão, há muito tempo, imersos no tecido social urbano. 
A utilização do termo "imigrante", "imigrado" ou qualquer neologismo ou eufemismo que se prolifera atualmente, não são qualidades e sim expressões que se referem de modo exterior a uma parte dos habitantes da cidade que são identificados como uma categoria sócio-política diferenciada. O cuidado na utilização de certos conceitos é imprescindível para reconhecer as circunstâncias atuais e históricas em que determinada terminologia foi forjada e é utilizada. Nesse sentido, Foucault (2001), analisa como os conceitos e as definições criados pelos cientistas, nascidos e educados em sociedades específicas, terminam adotando os pressupostos ou as omissões da visão oficial. É nesse sentido que Sayad (1998) insiste que "não se pode escreve inocentemente sobre a imigração e sobre os imigrantes; não se pode escrever sem se perguntar o que significa escrever sobre esse objeto, ou, o que é o mesmo, sem interrogar-se acerca do estatuto social e científico desse mesmo objeto" (Sayad, 1998: 21).

Ao pensar a denominação "imigrante" inserido dentro da lógica urbana, conforme foi observada de modo profundo por Simmel, Halbawachs, Mead e os teóricos da Escola de Chicago, não resta dúvida que àquele a quem se nomeia imigrante não é uma figura objetiva, senão um personagem imaginário, em que recai um atributo carregado de princípios negativos, cuja intencionalidade passa pela ordem ideológica. Dessa forma se atribui ao imigrante um caráter de temporalidade e de diferenciação no espaço social. No entanto, a estrutura urbana está constantemente estruturando-se através de relações humanas marcadas por mobilidades, fragmentações e equilíbrios descontínuos. A heterogeneidade, a simbiose e a diversidade que existe na cidade são irrestritas e todos os seus habitantes estabelecem relações fortuitas de interdependência nas diversas redes e canais existentes dentro da teia urbana.

O jogo simbólico que está por trás da própria denominação imigrante, presente tanto na Espanha como em outros países da Europa, opera no sentido de marginalizar determinados grupos, fazendo com que ocupem lugares inferiores no sistema social. Inclusive no caso de pessoas que gozam plenamente dos mesmos direitos jurídicos e políticos do Estado-nação, como no caso dos imigrantes que obtiveram a dupla nacionalidade eles estão condenados a viver à margem, nos lugares inferiores da estrutura 
social. Ainda que tenham o direito de eqüidade perante a lei, são vistos socialmente como atrasados e com dificuldades de entender o "universo cultural" da sociedade receptora.

A propósito, essa operatividade simbólica fica mais evidente quando se percebe como a designação daquele que poderia ser denominado como "imigrante" pode variar de acordo com o contexto sociopolítico de determinado lugar. A Espanha pode ser citada como um bom exemplo para ilustrar esse raciocínio. Nas últimas duas décadas, com a afluência de imigrantes originários fundamentalmente da África, da América Latina e da chamada Europa do Leste, a Espanha se consolidou como um país receptor de trabalhadores estrangeiros, e a imigração nesse país foi profundamente resignificada. Os imigrantes internos foram pouco a pouco perdendo seu "grau de imigridade". As pessoas procedentes de outras regiões da Espanha, que eram denominadas pejorativamente, por exemplo, como "xarnegos" ou "maketos", na Catalunha e no País Basco, respectivamente, ficaram invisibilizados com a chegada dos imigrantes estrangeiros. Já os chamados "moros" ou "sudacas", como são conhecidos de modo pejorativo os árabes e os latinoamericanos, respectivamente, foram ganhando um lugar de diferente e estranho, que antes pertencia aos imigrantes internos. Se em um passado recente, as pessoas vistas como perturbadoras da paz social, como barulhentas, com um sotaque "deselegante", mal educadas, com um temperamento agressivo e com costumes que, inclusive, poderiam ameaçar a integridade cultural da comunidade receptora eram os chamados imigrantes internos, na atualidade os imigrantes externos passaram a ser culpabilizados de todos os males possíveis.

O próprio Estado-nação se encontra diante de imprecisões, também carregadas de sentido ideológico, na hora de definir esse "personagem conceitual", por fazer eco a um pensamento de Deleuze. Nem a toda pessoa que abandonou seu território de nascimento é auferido o mesmo qualificativo de imigrante. Dessa forma, as denominações de "estrangeiro" e de "imigrante" recebem um reconhecimento distinto. Para Sayad (1998), ambas as expressões não implicam, necessariamente um mesmo estatuto social. No que se refere ao marco jurídico, existe uma legislação que regula o estrangeiro, seus direitos e seus deveres, com relação à sua presença e permanência dentro do território. Já do ponto de vista social, surge a figura de "imigrante". Enquanto a denominação de estrangeiro, em geral, 
está associada a um indivíduo procedente de uma nação economicamente desenvolvida, a de imigrante significaria, justamente, o contrário, uma pessoa que é natural de um país ou lugar economicamente menos favorecido, que tem um umbral de pobreza muito grande e por isso "exporta" imigrantes.

Essa fronteira não é tão rígida, pois mesmo dentro de um mesmo grupo nacional que é identificado como um país de emigrantes, algumas pessoas podem ter um status social de "estrangeiro", como é o caso de diplomatas, artistas, estudantes, esportistas, entre outros. Nem toda pessoa que deixou seu país para instalar-se em outro, recebe o mesmo qualificativo de imigrante. Apenas se reconhece como imigrante os que fizeram um deslocamento relativamente precário e que estão destinados a ocupar os espaços mais inferiores do sistema social no lugar da imigração. Na Espanha há casos exemplares para ilustrar tal diferenciação. Segundo Salvá Tomas (2002), enquanto muitos latino-americanos são estigmatizados como imigrantes nas Ilhas Baleares, a grande quantidade de Alemães que também vivem no mesmo território, são tratados como estrangeiros.

Dessa forma, os processos da migração internacional se configuram na ordem das nações, em que de acordo com Sayad (1998), enquanto o chamado "mundo dominante" produz principalmente turistas, empresários, estudantes internacionais, aposentados, entre outros, o "mundo dominado" produziria basicamente mão-de-obra imigrante. Desse modo, o desigual e injusto ordenamento internacional, se reproduz também dentro da própria sociedade de imigração.

Em um mundo que se imagina globalizado, o paradoxo para os mais pobres está precisamente na existência de muros, de fronteiras e de um trato assimétrico entre os Estados nacionais. Este mapa atual transpassa ao cotidiano dos imigrantes, criando um cenário dominado por preconceitos, discriminação e exploração.

Por outro lado, a própria condição de imigrante constitui um estado ambíguo, que oscila entre a transitoriedade que lhe é atribuída e o caráter permanente do projeto migratório. Em outras palavras, na vida cotidiana do imigrante se exige que ele cumpra com os requisitos de uma pessoa que está "integrada" permanentemente na sociedade, ao mesmo tempo em que, tanto socialmente, como de direito, ele carrega sempre a suspeita e a 
desconfiança de uma suposta provisionalidade. Aqui reside o paradoxo de que o imigrante deve "integrar-se" de forma cada vez mais permanente, mas sempre com o reconhecimento provisório da sua condição.

Em suma, a terminologia "imigrante" está constituída por sentidos sociais e políticos que podemos considerar como sendo paradoxais. Parafraseando a Bourdieu (1998), o imigrante apenas pode estar nesse lugar que não é nem cidadão, nem estrangeiro; ele ocupa essa fronteira entre o ser e o não-ser social. Incomodo em todo lugar, ele obriga a repensar completamente a questão dos fundamentos legítimos da cidadania e da relação entre o Estado e a Nação ou a nacionalidade.

\section{Brasileiros na borda do preconceito: imigrantes ou estrangeiros?}

$\mathrm{Na}$ recente caracterização do Brasil como um país marcado pela emigração, os países da Europa têm representado um destino favorito para muitos brasileiros. Essa escolha tem despertado a atenção de muitos pesquisadores, que através de distintos olhares teóricos tentam entender e analisar o processo da imigração brasileira na Europa ${ }^{8}$. No entanto, enquanto em países como Portugal e Itália, por exemplo, existe uma relativa diversidade de trabalhos sobre a comunidade brasileira, em outros paises o processo é completamente oposto ${ }^{9}$. Além disso, existem profundas diferenças em relação à presença numérica, tempo de chegada, modos de entrada, redes migratórias, ocupação do espaço urbano, atividades exercidas e muitas outras especificidades que diferenciam a presença dos brasileiros em distintos países da Europa.

Como já foi sinalizado anteriormente, no sentido inverso do Brasil, a Espanha se viu marcada por um veloz processo de mudança no rumo migratório: passando de ser um país emissor de emigrantes a ser receptor, assim como de uma forte imigração interna para uma

\footnotetext{
${ }^{8}$ Como por exemplo os trabalhos de Machado (2003), Huber (1999), Salvodi (1997) e Torresan (1994).

${ }^{9}$ Assim é o caso da Espanha, que até a atualidade a única pesquisa conhecida sobre a presença brasileira nesse contexto é a tese doutoral do autor, consultar Cavalcanti (2003).
} 
imigração estrangeira. Os números são testemunhas desse giro. As pessoas de procedência estrangeira com residência na Espanha representavam 2,3\% da população em janeiro de 2000. Em um percurso de cinco anos, essa mesma cifra subiu a $8 \%$, segundo os números de janeiro de 2005. Acompanhando esse crescimento, os brasileiros também registraram um notável aumento, passando de 13.730, no início da década, a 53.700, em janeiro do corrente ano. Apesar de representar um número pequeno, comparado com os quase 3.700 .000 estrangeiros que vivem nesse país, o coletivo brasileiro vem crescendo de modo significativo no contexto da imigração estrangeira na Espanha ${ }^{10}$.

No entanto, como em toda realidade migratória, é importante apontar que os números sempre carecem de uma precisão, mais ainda se esse número se refere aos países da comunidade européia, onde as cifra podem subir ou baixar se incluímos àqueles que têm dupla nacionalidade, os que por alguma circunstância se declararam residentes em outras zonas da Europa, os que estão registrados em outras regiões da Espanha, os que entraram com visto de turista por outros países europeus e uma grande quantidade de pessoas que atualmente se encontram sem a autorização de residência e trabalho, que não figuram nos registros oficiais, mas fazem parte do coletivo.

Semelhante ao que acontece em outros países europeus, os símbolos que evocam ao Brasil aparecem gravados nas ruas e calçadas das diferentes cidades espanholas. Camisetas da seleção brasileira, fotos e símbolos do Brasil ganham vida nas principais regiões da Espanha. No entanto, se por um lado, os elementos que simbolizam a presença brasileira são facilmente identificáveis, por outro, não resulta uma tarefa fácil identificar os imigrantes brasileiros. Os próprios autóctones, ao serem indagados sobre como eles percebiam a presença brasileira na Espanha, muitas vezes, respondiam de modo contundente: "aqui quase não tem imigrantes brasileiros, a maioria dos brasileiros que estão aqui são estudantes ou jogadores de futebol, imigrantes mesmo são os equatorianos, marroquinos, colombianos e toda essa gente." Trata-se de uma imigração recente e que cresce rapidamente, ainda que não tenha sido visualizada pela mídia, pela academia, pelo discurso político, nem pela opinião pública em geral.

\footnotetext{
${ }^{10}$ Dados do Instituto Nacional de Estatísticas (INE), consultada em $\underline{\text { http://www.ine.es/inebase, último acesso }}$ em 29 de abril de 2005.
} 
As cidades de Madri e Barcelona, bem como toda a região costeira, são pontos de destino preferidos pela maioria dos brasileiros residentes na Espanha. Com referência a data de chegada do mencionado coletivo, constata-se que o começo de um fluxo migratório importante se estabelece a partir da segunda metade da década de 1990 e vem crescendo constantemente até os dias atuais.

O grupo dos brasileiros está formado, a priori, por uma composição heterogênea em relação ao gênero, a idade, ao grau de instrução, a ocupação profissional, a cor da pele, as origens territoriais, sociais, econômicas, etc. Um grupo que se caracteriza justamente pela sua diversidade e procede das mais distintas regiões do Brasil, não havendo uma predominância de nenhuma cidade, estado ou zona específica. Esta observação contrasta com outros estudos sobre a imigração brasileira nos Estados Unidos, como por exemplo, os trabalhos de Sales (1999) e Martes (2000), que constataram uma forte e predominante presença, no estado de Massachusetts, de brasileiros procedentes de uma determinada região do Estado de Minas Gerais.

Como se trata de uma imigração relativamente recente, não é uma tarefa complicada encontrar os brasileiros pioneiros desse fluxo. Muitos chegaram sem conhecer ninguém e arriscaram suas economias, apostando por esse caminho. Por outro lado, estão aqueles que chegaram à raiz das primeiras redes migratórias estabelecidas. Dessa forma, através de familiares e conhecidos, os brasileiros estão cada vez mais criando estratégias migratórias próprias que facilitam a obtenção de recursos e materiais para empreender seus projetos migratórios e que ajudam, inclusive, no desenvolvimento de uma vida cotidiana de acordo com as suas aspirações.

Por tratar-se de um grupo que apresenta um breve tempo histórico, os brasileiros formam um coletivo pequeno. Em consequiência, ocupam o território na metrópole sem uma concentração específica em determinado lugar. Desse modo, pelo fato de estarem dispersos, têm a impressão de que são mais tolerados frente a outros coletivos. Assim, outros grupos de imigrantes, com uma presença numérica maior, como é o caso dos equatorianos e marroquinos, ocupam os lugares de forma mais concentrada e, portanto, são mais visualizados e estigmatizados. Os brasileiros, ao contrário, estão mais dispersos, 
levando a cabo distintas atividades laborais e formando amplos vínculos de amizades, tanto com outros latino-americanos, como com estrangeiros em geral.

Dentro do mencionado coletivo, registra-se uma forte desigualdade econômica. Assim, enquanto existem brasileiros que chegam a dividir sua própria cama, fazendo uso da conhecida estratégia da cama quente, para poder ter os meios necessários para sobreviver, existem outros, com uma razoável conta bancária e, inclusive, quando as "coisas apertam", recebem ajuda de algum familiar radicado no Brasil. Também é possível observar que no interior do coletivo, a experiência migratória permite relegar, ao menos de forma circunstancial e estratégica, as diferenças de origens entre os seus membros. Assim, por exemplo, quando um grupo de brasileiros se reúne para comer uma "feijoada", é possível perceber que as "distâncias" pertinentes à formação escolar e profissional, a situação econômica de procedência, a origem regional, os rasgos fenótipos, entre outros aspectos, que no Brasil pudesse ter sido motivo para um distanciamento, pelo contrário, no país de imigração, tendem a ser minimizados diante da situação comum de ser imigrante.

A própria mescla e diversidade existente na sociedade brasileira se reproduz no contexto espanhol. Os brasileiros podem facilmente se passar por africanos, árabes, asiáticos, europeus, etc., dado a profunda mestiçagem existente nesse coletivo. Essa diversidade permite uma relativa invisibilidade, que consiste em ser visto porque se visualiza, mas não pode ser reconhecido aparentemente como imigrante brasileiro.

Desse modo, os que são mais negros ou mulatos e, portanto, mais parecidos com os africanos ou árabes, respectivamente, são mais estigmatizados. Não está demais recordar que o "estigma", como nos advertiu Goffman (1989), é um processo que se mantém a partir de duas funções sociais: o normal e o estigmatizado. Os brasileiros mais parecidos ao imaginário do fenótipo europeu afirmam que dificilmente passam por alguma situação constrangedora, como por exemplo, ser parado por um policial na rua ou sentir um tipo de olhar que denuncia alguma diferença. Eles se sentem considerados, ainda que seja somente em aparência, como "normais". Enquanto aqueles que levam na pele o estigma de ser identificado como imigrante, afirmam que esse fato implica estar à mercê de uma 
percepção que lhe marca em um lugar socialmente diferenciado. A fala de Edgar, a seguir, ilustra essa complexidade:

"Quando eu saio para tomar um café ou mesmo de festa, eu prefiro sempre estar acompanhado de pessoas que são brancas ou européias, porque assim ninguém te pára. Eu que sou negro, se não tomo cuidado a polícia vai sempre me parar, mas se eu estou misturado com outros que parece gente daqui ou mesmo com europeus, eles vão sempre pensar que sou um negro dos Estados Unidos ou da Inglaterra e nunca vão me parar, mas se eu estiver com outros negros ou mulatos me param na cara. Se uma pessoa que é muito diferente do pessoal daqui e não tem os papéis, o melhor é evitar estar acompanhado com outras pessoas também muito diferentes, porque termina chamando muita atenção.” (Edgar, 26 años, 2 en Barcelona. Trabajo de campo 2002).

Dessa maneira, os imigrantes mais estigmatizados tomam consciência dessa percepção através dos olhares insistentes dos autóctones, das abordagens dos policiais solicitando documentação, no impedimento de entrar em determinados bares e discotecas, ou com tantos outros motivos que os colocam em uma posição social de "diferente" e “outro”. Nesse sentido, o próprio Goffman (1989) faz alusão aos possíveis inconvenientes e dificuldades que circundam o contato direto quando um indivíduo pertence a uma categoria socialmente estigmatizada. Assim, quando um atributo define uma pessoa como diferente ou inferior, isso influencia e condiciona as relações com o resto dos indivíduos.

Assim, a presença brasileira no território espanhol permite contemplar com mais clareza a fragilidade epistemológica da utilização do termo "imigrante" como uma categoria objetiva das ciências sociais. Ao observar as diferentes nuances do coletivo brasileiro na Espanha, fica evidente que quando se denomina a determinadas pessoas com o rótulo de "imigrante", não se obedece a um principio de realidade, ao contrário, se trata de construir um personagem imaginário marcado por princípios negativos e com um estigma atemorizador. Entre as milhares de pessoas que deixaram seus países de origem para viver em outro, apenas alguns são taxados pejorativamente como "imigrantes". 
Por outro lado, a prática discursiva em relação ao imigrante está dotada de sentidos e ênfases que convertem a esse personagem em uma figura que gera pânico social. Na Espanha, por exemplo, enquanto os cientistas sociais das mais diversas províncias espanholas vêm denominando de "fenômeno" a imigração não-comunitária, o discurso político, os meios de comunicação e a opinião pública em geral a classificam como um "problema" ". Essa identificação da imigração como um "problema" se viu refletida nas pesquisas de opinião publica ${ }^{12}$, revelando que a imigração já se constitui como o terceiro "problema” para a população espanhola, só ficando atrás do desemprego e do terrorismo do grupo ETA. Assim, essa representação promove sentimentos de incômodo, insegurança ou medo com respeito aos imigrantes. A denominação de "problema" para definir o "fenômeno" da imigração, apresentando-o como uma ameaça à estabilidade social do Estado, bem como as contínuas medidas sociojurídicas e administrativas que limitam a cidadania do imigrante e os crescentes discursos que exaltam a homogeneidade cultural como condição do ideal de convivência social, traduzem-se, para Stolcke (1996), em uma nova retórica da exclusão na Europa.

Os imigrantes se vêem imersos nos mecanismos de vigilância e controle que alcançam de modo mais contundente aqueles rotulados como diferentes. Reconhecidos e caracterizados socialmente como tais, seja pelo seu aspecto físico, pelo seu modo de falar, pelos seus costumes específicos, seja por qualquer outro aspecto que possa considerar-se como um sinal de pertencer a um país menos desenvolvido economicamente, os imigrantes são distinguidos, paradoxalmente, como "gente diferente" na cidade.

Dessa maneira, são freqüentes os interrogatórios a que são submetidos os imigrantes, que podem vir tanto de policiais que lhes surpreendam enquanto passeiam pelos espaços públicos, como de um companheiro de trabalho, de estudo ou de qualquer cidadão.

\footnotetext{
${ }^{11}$ Ao se referir à opinião pública, à mídia e ao universo político, o texto não pretende assumir uma atitude generalista, tampouco afirmar que todos os espanhóis têm atitudes xenófobas ante o imigrante. Na Espanha, também existe um debate coerente que se propõe a "historicizar" a imigração e reflexioná-la de modo mais dinâmico. Além do mais, existem cerca de quatro milhões de espanhóis que participam ativamente como voluntários em instituições que trabalham, entre outras coisas, diretamente com os imigrantes. Assumir uma visão generalista, seria cair numa atitude preconceituosa com a academia e com uma significativa parcela da sociedade espanhola.

${ }^{12}$ Dados dos Barómetros de Opinión del Centro de Investigaciones Sociológicas, CIS, consultada em http://www.cis.es/bd estudios.asp?tema=23, último acesso em 29 de novembro de 2002.
} 
Cotidianamente questionados e vigiados, para utilizar uma metáfora foucaltiana, os imigrantes são percebidos imaginariamente como "outro", a partir de aspectos que acentuam a sua "estrangeria". Distinguido por supostas "diferenças" culturais, raciais, fenótipas, entre outras, o imigrante fica cada vez mais vulnerável ao controle que o limita social e culturalmente.

Um sujeito que acaba convertendo-se, paradoxalmente, em "outro", o que não deixa de ser um paradoxo, pois atribuir a determinados personagens urbanos o estereótipo de "diferente" seria escorregar em um pleonasmo, dado que nos contextos urbanos todo mundo é de fato um "outro" entre muitos "outros". O paradoxal é que em cidades como Madri e Barcelona, por exemplo, consideradas como "cidades globais", para utilizar uma expressão de Sassen (1991), em que se pode confirmar que o núcleo central dessas sociedades está caracterizado justamente pela diversidade, em que todos são de fato "diferentes" e "outros", entretanto aos imigrantes sobram os discursos que os estigmatizam e rotulam as suas diferenças. Aqui se está diante de um paradoxo das sociedades contemporâneas, nas quais todas as "diversidades" não são igualmente valorizadas.

A imaginária e paradoxal condição de "imigrante" na cidade, coloca a pessoa diante de situações de extrema vulnerabilidade. O alarmante aumento de atitudes hostis e violentas, que se observam na Espanha, contra os chamados imigrantes do terceiro mundo, têm sido manifestadas constantemente. Na Europa, em geral, as ações dos grupos considerados de extrema direita ou inspirados em ideologias fascistas, como por exemplo, o conhecido grupo "neo-nazista", vem atemorizando constantemente aos imigrantes. O seguinte relato ilustra esse fato:

\footnotetext{
"Eu tenho muito medo de andar em ruas escuras, por becos do bairro gótico ou então por um daqueles lugares mais isolados de Barcelona, mas meu medo não é de fantasma ou coisa desse tipo, o que eu tenho medo mesmo é desse povo nazista que ataca imigrante. Como eu sou parecido a um árabe e com esse meu sotaque de brasileiro que se reconhece de longe sou um alvo certo. Eu tenho muito medo que eles me peguem e me encham de porrada ou até mesmo me matem. Eles são muito covardes porque atacam em bando e a gente pode ser um só.
} 
Isso me dá muito medo, porque aqui eu não tenho família nem amigos para me ajudar, imagina só se eu fico internado no hospital, aqui nessa terra que não é a minha, e longe de todo o apoio. Deus que me livre de tal coisa!" (Flavio, 30 años; 2 en Barcelona. Trabajo de campo 2002).

Por outro lado se está produzindo o fortalecimento de partidos políticos de extrema direita, que defendem com dureza a repressão contra os imigrantes como uma das principais bandeiras políticas. Um exemplo notável foram as teses xenófobas utilizadas na última eleição da Suíça, que levaram ao poder Christoph Blocher, líder do partido de extrema direita suíço, o qual defendia, na campanha eleitoral, entre outras coisas, que "o mal vem de fora". Da mesma forma, no outro lado do atlântico também é possível observar modelos semelhantes. Um caso significativo é o aumento do número de pessoas que se alistam nos chamados grupos "caça-imigrantes", nos Estados Unidos, como por exemplo, os participantes do "Minute Man Project", que vem preocupando diversas organizações e ativistas de direitos humanos. Essas atitudes xenófobas ou racistas põem em cheque os ideais de uma sociedade plural e tolerante, sobre o qual estão baseadas as consciências axiológicas de muitas sociedades ocidentais.

O "imigrante", constantemente apontado como dono de um lugar diferenciado, lugar do outro, do estranho, do intruso, do forasteiro é geralmente associado a um problema a ser resolvido, quando, na verdade, representa a vitalidade, a renovação e a continuidade da cidade. Essas contradições não deixam também de denunciar alguns dos paradoxos do mundo contemporâneo, pois, de acordo com Garcia Canclini (1990), ao mesmo tempo em que vivemos em uma época de fraturas e heterogeneidades, de segmentações dentro de cada repertório nacional, cujos próprios grupos locais se comunicam e se identificam de forma fluida com ordens e símbolos transnacionais, não cessam os discursos que não se cansam em plantear que a presença dos chamados imigrantes representa uma "ameaça" e um "problema" para as cidades contemporâneas. 


\section{Conclusão}

Observar a dinâmica dos brasileiros na Espanha não constitui uma tarefa fácil, pois, apesar de que nos últimos anos a imigração brasileira vem crescendo consideravelmente nesse país, existem profundas diferenças, em diversos aspectos, que caracterizam a presença dos brasileiros no território espanhol. No entanto, isso não invalida uma pesquisa baseada num exaustivo trabalho de campo, dado que todo processo de reflexão intelectual é de uma progressão interminável, como nos ensina o mito de Sísifo. ${ }^{13}$

Não cabem dúvidas que a imigração se constitui como um fato coletivo que é constantemente influenciado por distintos ordenamentos econômicos e sociais. Os diferentes itinerários de ordem pessoal que se formam através das diferentes trajetórias e experiências dos migrantes, constituem também um vetor importante para compreender e analisar dita temática. Como "fato social total", a migração está formada por deslocamentos das pessoas no espaço geográfico, mas também em outros espaços, como podem ser o social, político, econômico ou cultural (Sayad, 1998).

No entanto, as temáticas relacionadas ao êxito e às contribuições dos imigrantes nos diversos campos sociais, assim como os aportes das suas experiências de vida e das ações não-estereotipadas, são, com freqüência, desvalorizadas. Ao contrário, como "bodes expiatórios" de todos os males, os imigrantes são injustamente acusados pelas principais questões que preocupam a população. O desemprego, o aumento da insegurança, a deterioração dos serviços sociais, a escassez da moradia, entre outras temáticas que preocupam também o chamado primeiro mundo, são, muitas vezes, responsabilizadas pela "excessiva" presença dos imigrantes. Muitos são os líderes de partidos conservadores e da extrema direita que não se cansam em argumentar que os estrangeiros são os responsáveis por todas as desgraças morais e sociais. Ao acusarem de modo pragmático e mágico os

\footnotetext{
${ }^{13}$ Mito grego no qual Sísifo, sendo um intelectual, é condenado a empurrar por toda a eternidade uma rocha até o cume de uma montanha, de onde a pedra voltaria a cair pelo seu próprio peso, o que implicava realizar o trabalho novamente.
} 
imigrantes, "esquecem-se" de debater as principais causas da recessão econômica e do ajuste capitalista que atinge praticamente toda a economia mundial.

Além disso, é importante observar que ao largo da história os intercâmbios culturais enriqueceram o sentido humano. Assim se sucedeu com a arte, a música, a literatura, a ciência, etc., que fizeram considerar seu valor além da sua origem nacional como, por exemplo, uma obra de Dali ou de Gaudi, que hoje pertencem ao universo cultural da humanidade. Resultaria um exercício incoerente imaginar as descobertas de Einstein, os escritos de Lévi-Strauss, os clássicos gregos, os textos de Marx, as obras de Freud, etc., como algo "nacionalizado". No entanto, no contexto da migração ainda prevalece o rótulo da "nacionalidade" ou "etnicidade", estando os imigrantes, muitas vezes, impedidos legalmente de vivenciar a internacionalização e de atuar como protagonistas dos intercâmbios culturais.

Da mesma forma, não se trata de desconhecer as diferentes formas de organização de vida e os distintos sistemas de significados dos grupos humanos. Não cabem dúvidas de que a diversidade cultural exista por si mesma e que há uma diferença objetiva entre comunidades diferenciadas, apesar de que, como ensinou Barth (1976), esse tipo de identidade se forma em contraste com outros grupos. No entanto, o objetivo, aqui, não é entrar no mérito da discussão sobre a formação da identidade étnica, ao contrário, a intenção é apontar como se utiliza, politicamente, a diversidade cultural para excluir determinados grupos, ativando suas supostas diferenças para limitar e impedir qualquer possibilidade de estar em contato.

Assim, a dualidade, de certo modo esquizofrênica e carregada de um sentido ideológico, cria, de um lado, os autóctones, aqueles considerados "daqui”, e, de outro lado, os denominados imigrantes, os que são de "fora" e que deverão estar situados nas escadas mais baixas do sistema, porque são "perigosos" para a organização social e "ameaçam" a integridade e a pureza cultural e identitária. Entretanto, esse tipo de ordem, apesar de contradizer toda a lógica urbana, revela-se muito útil para a instalação de um preconceito e de uma discriminação que estará marcada por uma diferenciação e hierarquização. Em suma, está-se diante de novas formas de racismos cada vez mais sutil e cruel. 


\section{BIBLIOGRAFIA}

BARTH, F. Los grupos étnicos y sus fronteras. México: FCE, 1976.

CACHÓN, L. La formación de la 'España inmigrante': mercado y ciudadania. Madrid: Revista Española de investigaciones sociológicas, Nº 97, pág. 95-126, 2002.

CASTELS, S. y MILLER, M. J, eds. The age of migration international population movements on the modern world. Houndmills: Macmillan, 1993.

CAVALCANTI, Leonardo. Los inmigrantes brasileños en la ciudad de Barcelona: un estudio antropológico sobre sus estrategias migratorias y su vida cotidiana. Tesis doctoral, Dept. de Sociología, Universidad de Salamanca: Salamanca, 2004.

COLECTIVO IOÉ La inmigración extranjera en España. Barcelona: Fundación La Caixa, 1999.

DELGADO, Manuel. Ciutat i immigració. Barcelona: Centre de Cultura Contemporània de Barcelona, 1996.

FOUCAULT, Michel. Las palabras y las cosas: una arqueología de las ciencias humanas. México: Siglo XXI, 2001.

GARCÍA CANCLINI, Néstor. Culturas híbridas: estrategias para entrar y salir de la modernidad. México: Grijalbo, 1990.

GOFFMAN E. Estigma. La identidad deteriorada. Buenos Aires: Amorrorru, 1989.

HUBER, Luiza "Nos Trajetos da Sujeição: As Brasileiras na Suíça." Travessia - Revista do Migrante 26 (Sept-Dec): 35-37, 1996.

MACHADO, Igor José de Reno. Cárcere Público: Processos de Exotização entre Imigrantes Brasileiros no Porto, Portugal. Tese doutoral, Instituto de Filosofia e Ciências Humanas, UNICAMP, Campinas, 2003.

MARTES, Ana Cristina Braga. Imigrantes brasileiros em Massachussets. São Paulo: Paz e Terra, 1999.

MASSEY, D. Worlds in Motion: Understanding International Migration at the end of the millennium. Oxford: Clarendon Press, 1998. 
REIS, Rossana Rocha e SALES, Teresa Cenas do Brasil migrante. São Paulo: Boitempo, 1999.

SALES, Teresa. Brasileiros longe de casa São Paulo: Editora Cortez, 1999.

SALVÁ TOMÀS, P. La mediterrània Occidental: un espai de crü̈lla de gran mobilitat demográfica intercontinental. Simposi Internacional "Europa mediterrània. Politiquees d'immigració". Barcelona: Institut de la Mediterrània, 2002.

SAVOLDI, A. O Caminho Inverso: A Trajetória dos Descendentes de Imigrantes Italianos em Busca da Dupla Cidadania. Tese doutoral. Departamento de Antropologia Social, Universidade Federal de Santa Catarina, 1997.

SASSEN, S. The global city: New York, London, Tokyo, Princeton Universtity Press, 1991.

STOLCKE, V. "Talking Culture: New Boundaries, New Rhetoric of exclusion in Europe". Currently Anthropology Review 36, (1995) : 1-24.

SAYAD, Abdelmalek. A imigração ou os paradoxos da alteridade. São Paulo: Editora da Universidade de São Paulo, 1998.

SILVA, Sidney. Costurando sonhos. Trajetória de um grupo de imigrantes Bolivianos em São Paulo. São Paulo: Paulinas, 1997.

TORRESAN, Angela Maria de Souza. Quem Parte, Quem Fica: Uma Etnografia Sobre Imigrantes Brasileiros em Londres. Tese doutoral. Museu Nacional, Universidade Federal do Rio de Janeiro, 1994. 